\title{
Environmental Performance Assessment for the Preservation of the Historic District Colonial Williamsburg - Virginia
}

\author{
Safaa A. Hefnawy*, Walaa H. Hussien \\ Architectural Engineering Department, Pyramids higher Institute for Engineering and Technology \\ Cairo - Egypt \\ *(Coressponding author: safaa.hefnawy@yahoo.com)
}

\begin{abstract}
:
Sustainable preservation of the historic districts is a prerequisite for achieving improvements in the quality of the nations' life in environmental, cultural, and economic aspects. It is a powerful alternative to the historic districts' demolishing or deteriorating which usually occur as a result of neglect and lack of awareness of these areas' value and what they represent in history. In the United States, and precisely in the Southeastern and Mid-Atlantic regions, Williamsburg district in 1607 was the first permanent New World English colony. The preservation project of Williamsburg aimed to re-create the physical colonial environment and to facilitate education about the origins of the idea of America. At the late $20^{\text {th }}$ century, Colonial Williamsburg has become one of the most popular tourist destinations, as the preservation project managed to make Williamsburg a model of historic and architectural authenticity. The objective of the present work is to review and analyze the preservation strategy used in Williamsburg district and its transformation to a model of historic and architectural authenticity. In addition, the research assesses the environmental performance of Williamsburg district to conclude the effect of the environmental performance on the preservation projects.
\end{abstract}

Keywords: Environmental performance; preservation; historical districts; Colonial Williamsburg

\section{Introduction}

In many countries historic sites are abandoned, demolished or deteriorated, so in the past few years the sustainable preservation of the historic districts has become a major challenge for authorities as it contributed the protection of these districts from deterioration. The motivation of the revival of historical sites will protect the history of such areas from being forgotten or extinct through preserving its historical and architectural values, as well as finding a way to afford its maintenance finance.

The studied case of Colonial Williamsburg district is a historical landmark and living-history museum represents one of the earliest settlements of the United States. It is now one of the largest history projects and a tourist attraction which immerse the visitor in the revolutionary spirit as the preservation of the district (buildings, streets, landscape and transportation) were almost all done in the authentic Colonial Revival style.
While there are many living history museums, Colonial Williamsburg is unusual for having been constructed from a living town whose inhabitants and post-Colonial-era buildings were removed.

Colonial-era buildings were by turns modified, modernized, protected, neglected, or destroyed. By the early 20th century, many older structures were in poor condition, no longer in use, or were occupied by squatters, but it was the only colonial capital still capable of being restored.

At the late $20^{\text {th }}$ century, Colonial Williamsburg has become one of the most popular tourist destinations in Virginia, as Colonial Williamsburg's Historic Area is a considered a compromise between historical authenticity and common sense and it was designated a National Historic Landmark District in 1960.

This paper focuses on assessing the Environmental performance for the preservation of Colonial Williamsburg. 


\section{Preservation of Colonial Williamsburg \\ 2.1 Identify the region historically and geographically}

Virginia: is a state in the Southeastern and MidAtlantic regions of the United States (Fig.1).

The area's history begins with several indigenous groups. In 1607 the London Company established the Colony of Virginia as the first permanent New World English colony [1].

Slave labor and the land acquired from displaced Native American tribes each played a significant role in the colony's early politics and plantation economy.

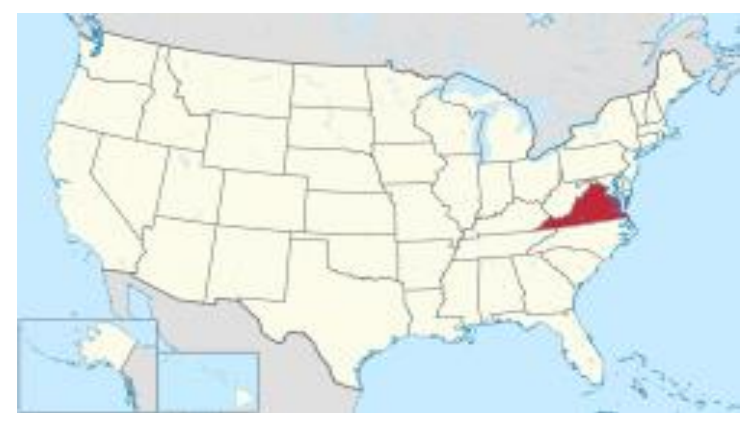

Fig.-1: Virginia State among the American states

The southern colonies were some of the first settled. It was settled by a group of workers from England who were meant to find anything profitable they could send back from their new colony. The ability to trade easily with Europe allowed for this.

Williamsburg -Virginia: For eighty-one years of the 18th century, Williamsburg was the center of government, education and culture in the Colony of Virginia (Fig.2). During the American Revolutionary War, in 1780 , the government moved to Richmond, on the James River, approximately 55 miles (89 kilometers) west, to be more central and accessible from western counties, and less susceptible of British attack [2].
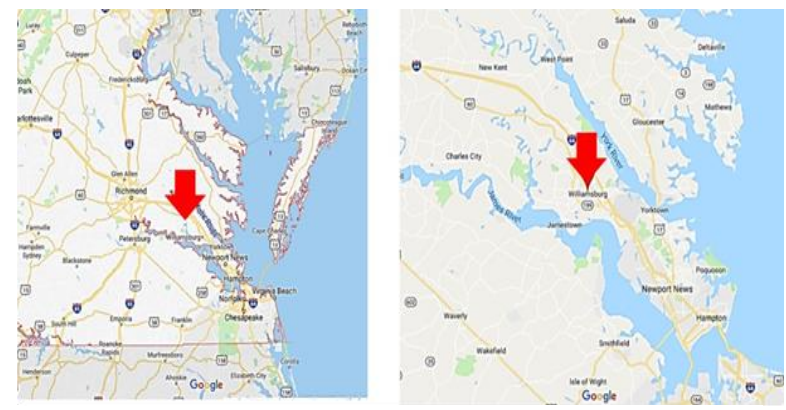

Fig.-2: map of Williamsburg the historical

The Historic Triangle is located in Virginia and includes the colonial communities of Colonial Williamsburg, Jamestown and Yorktown (Fig.3).

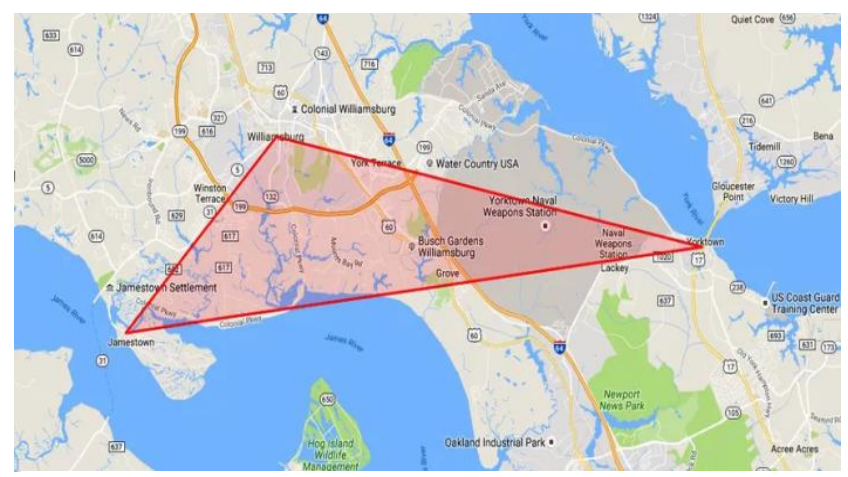

Fig.-3: The Historic Triangle in Virginia which includes the colonial communities of Colonial Williamsburg, Jamestown and Yorktown.

Colonial Williamsburg: Colonial Williamsburg's 301-acre, one of the earliest settlements of the United States, the historic area includes buildings from the 18th century (during part of which the city was the capital of Colonial Virginia), as well as 17th-century, 19th-century, and Colonial Revival structures, as well as more recent reconstructions (Fig.4).

Colonial Williamsburg was once used for conferences by world leaders and heads of state, including U.S. presidents.

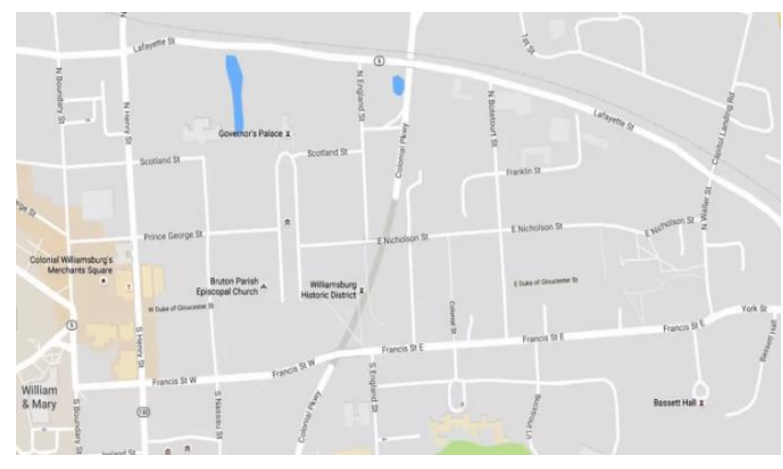

Fig.-4: Colonial Williamsburg

\subsection{The beginning and evolution of the Preservation}

The restoration of Colonial Williamsburg began as one man's dream and ended up as a national treasure and historic shrine.

The Reverend Dr. Goodwin became rector of Williamsburg's Bruton Parish Church in 1903. He assumed leadership of a campaign to restore the 1711 church building.

After several unsuccessful attempts to garner funds from philanthropists, Goodwin decided to solicit help from Rockefeller. Rockefeller saw in the deterioration of colonial-era buildings what saddened and inspired him. He renewed his associations with the "Association for the Preservation of Virginia Antiquities", which its membership included prominent and wealthy Virginians [3]. 


\section{Safaa A. Hefnawy, Walaa H. Hussien "Environmental Performance Assessment for the Preservation of the Historic District Colonial Williamsburg -Virginia”}

In the late 1920s, the restoration and re-creation of colonial Williamsburg was championed by community leaders.

\subsection{The aim of the Preservation}

The preservation of Williamsburg aimed to make it a model of historic and architectural authenticity; so the major goal of the Restoration was to re-create the physical colonial environment and to facilitate education about the origins of the idea of America, which was conceived during the decades before the American Revolution.

Colonial Williamsburg, the non-profit entity, is operated as a living museum which its motto has been: "That the future may learn from the past".

\subsection{The strategy of the Preservation}

The strategy is to immersing the visitor in the revolutionary spirit, in order to commemorate the rebel patriots and the early history of the United States.

Colonial Williamsburg's Historic Area's combination of restoration and re-creation of parts of the colonial town's three main thoroughfares and their connecting side streets attempts to suggest the atmosphere and the circumstances of 18th-century Americans [4].

One important notice here to be mentioned is that the only above core parts of the historic city had been selected to be treated as an open air museum. Although the larger these contexts would get the more heritages and environmentally sensible to the historic core, but then it would cause more disruptive of the continuity of the contemporary urban fabric and the dichotomy of services and infrastructure.

\section{The strategy procedures:}

\subsubsection{The buildings}

The Historic Area features a captivating cluster of restored original 18th-century structures and hundreds of buildings of houses, shops, and public buildings had been re-created on their original foundations, which related to its colonial and American Revolutionary War history (Fig.5)

Most of the restoration work focused upon the removal of any alterations that took place after 1800 (Fig.6) [5]. Prominent buildings include the Raleigh Tavern, the Capitol, the Governor's Palace, as well as the Courthouse [6].

The Governor's Palace and the Capitol building were reconstructed on their sites with the aid of period illustrations, written descriptions, early photographs, and informed guesswork (Fig.7) [7].

The foundation reconstructed the Capitol and Governor's Palace on their 18th-century foundations and preserved some below-ground 18th-century brickwork, classifying them as reconstructions.

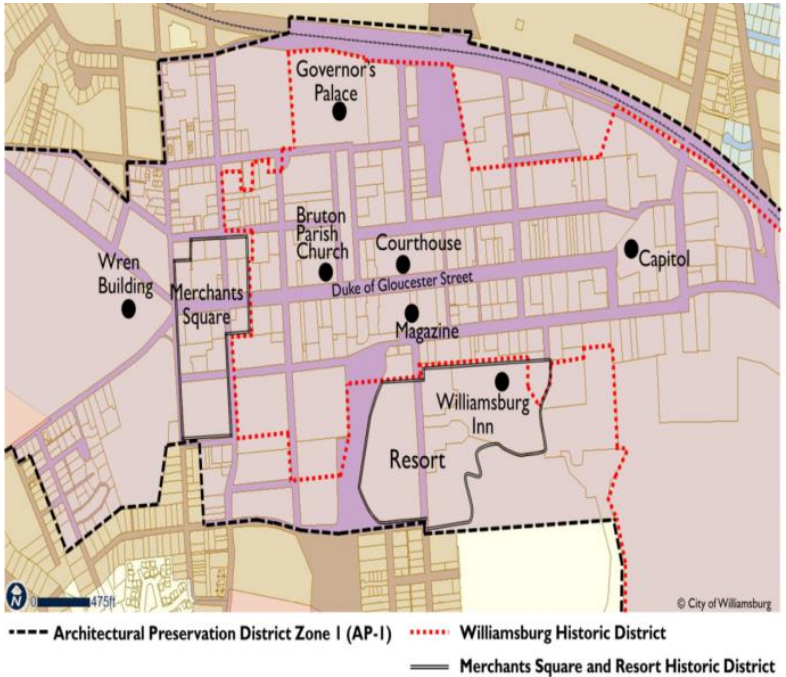

Fig.-5. Map of Colonial Williamsburg

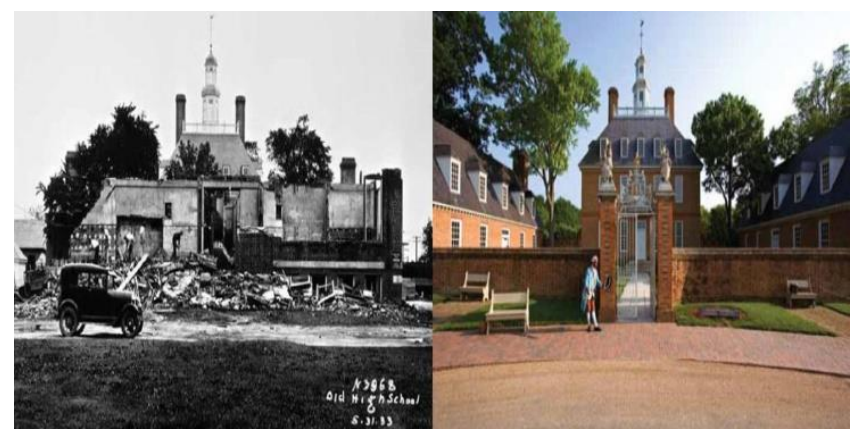

Fig.-6. Demolition of the High School in front of Governor's Palace (The Colonial Williamsburg Foundation)

Surviving colonial structures have been restored as close as possible to their 18th-century appearance, with traces of later buildings and improvements removed. Many of the missing colonial structures were reconstructed on their original sites beginning in the 1930s.

\subsubsection{The Landscape}

The grounds and gardens were almost all done in the authentic Colonial Revival style (Fig.8).

Beginning in the earliest period of the Restoration, Colonial Williamsburg acquired acreage in Williamsburg and the two counties which adjoin it, notably to the north and east of the Historic Area to preserve natural views and facilitate the experience of as much of the late 18th-century environment as possible (Fig.9) [8]. 


\section{Safaa A. Hefnawy, Walaa H. Hussien "Environmental Performance Assessment for the Preservation of the Historic District Colonial Williamsburg -Virginia"}
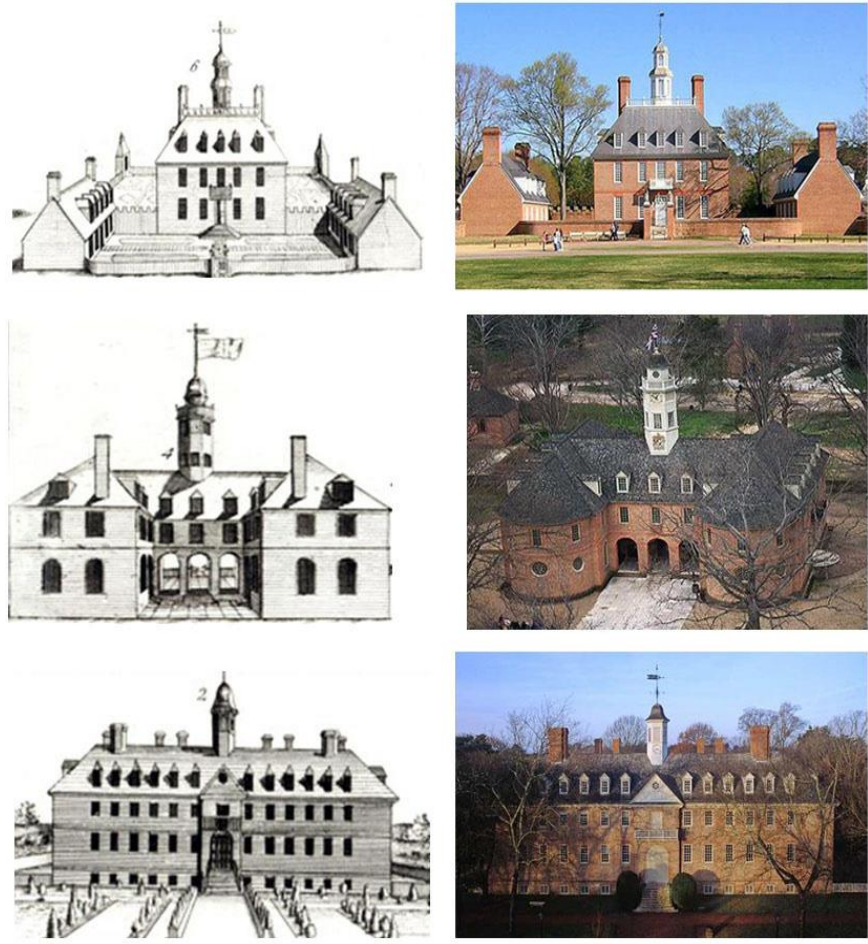

Fig.-7. Buildings as in the Bodeleian Plate (1740) and its Completion: Wren Building, Capitol, and Governor's Palace

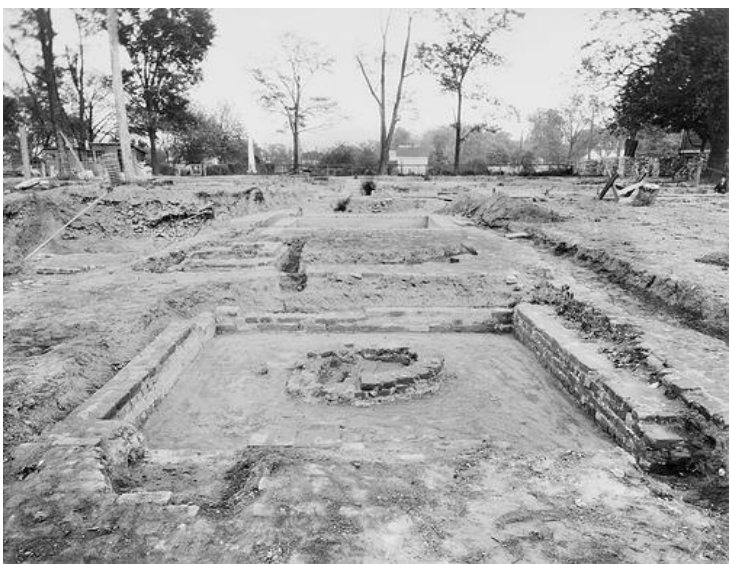

Fig.-8. setting the landscape with the same authentic colonial revival style

The entrance roadways to the Historic Area were planned with care. The Colonial Parkway was planned and is maintained to reduce modern intrusions (Fig.10).

The parkway is a 23 miles $(37 \mathrm{~km})$ scenic parkway linking the three points of Virginia's Historic Triangle, Jamestown, Williamsburg, and Yorktown (Fig.11). It is part of the National Park Service's Colonial National Historical Park. The Colonial Parkway is mostly covered by trees and is very shady in the summer and spring or beautiful in the fall and winter (Fig.12). It mostly looks like a Colonial trail or wagon road in the Colonial era with most of the wildlife and animals at the York River and the James River [9].

The traffic had been shifted away from the historic area; a large station in Colonial style is located just out of sight and within walking distance of the Historic Area (Fig.13) and bypass road was planned and built through farmland and woods about a mile north of town.

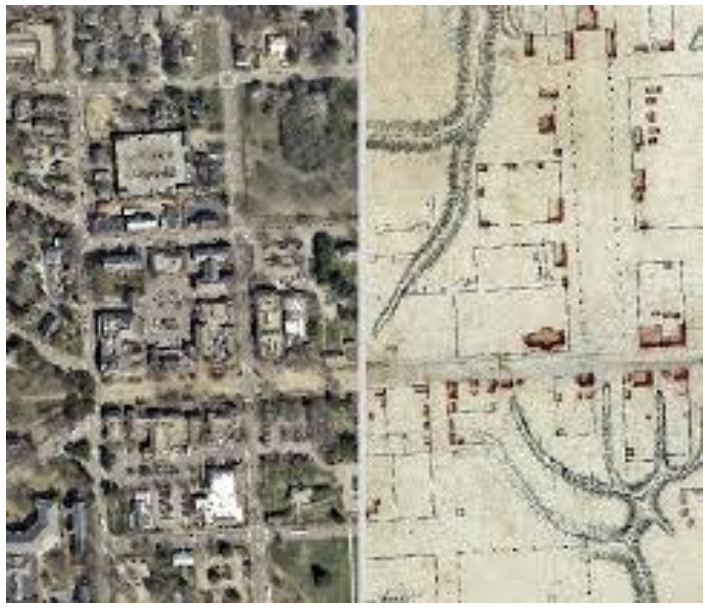

Fig.-9. Map shows the division of land and open spaces before and after restoration

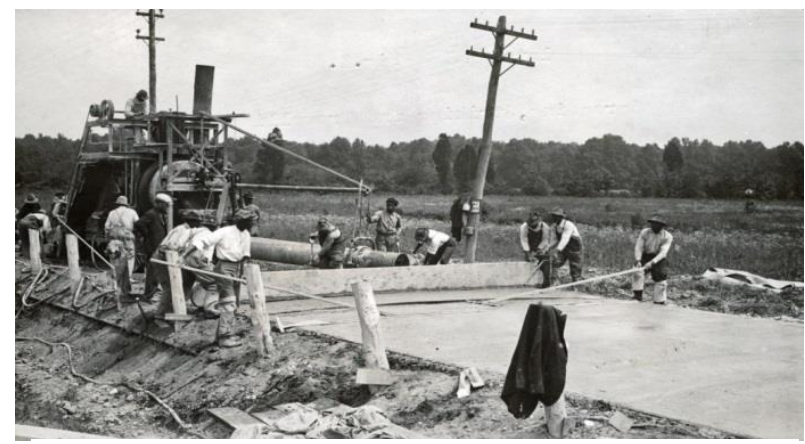

Fig.-10. Construction of the Colonial Parkway

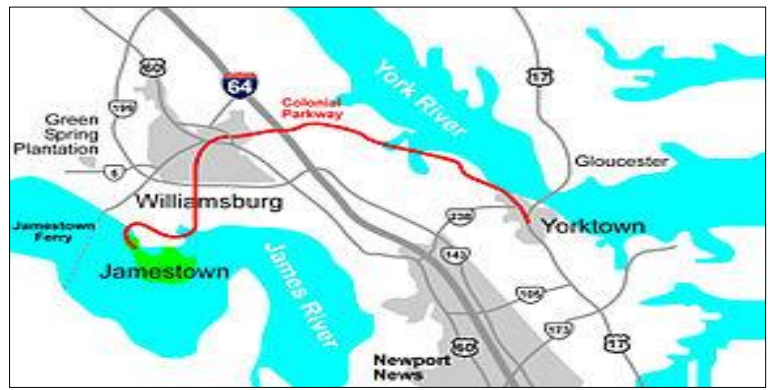

Fig.-11. map of Colonial Parkway, linking Colonial Williamsburg with Jamestown and Yorktown 

of the Historic District Colonial Williamsburg -Virginia"

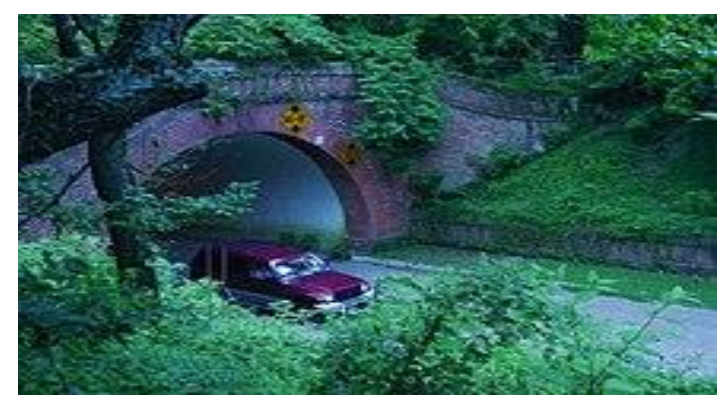

Fig.-12. Entrance to the tunnel of the Colonial Parkway, which runs beneath the historic area

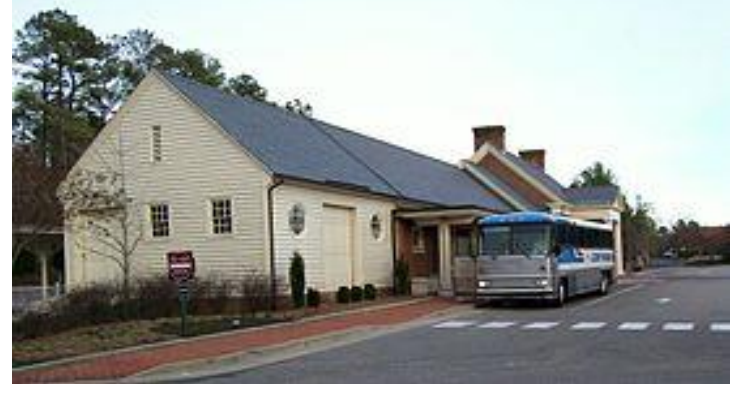

Fig.-13. Bus loading station in Colonial style within walking distance of the Historic Area

Automobiles are not permitted in the Historic Area, but shuttle-bus service is provided with designated stops, so inside the historic area only pedestrians, bicyclists, joggers, dog walkers, and animal-drawn vehicles are permitted (Fig.14).

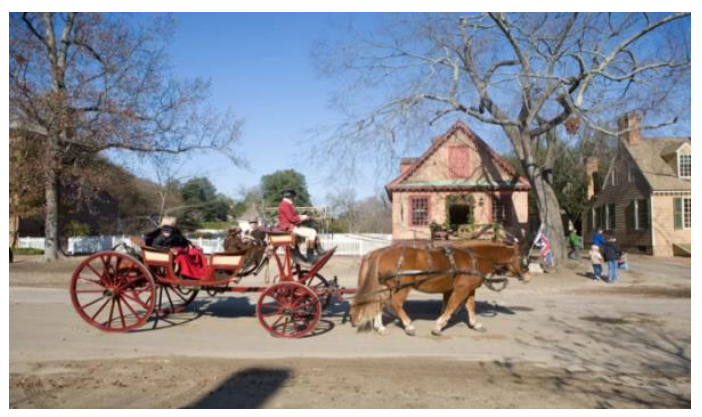

Fig.-14. Animal-drawn vehicles at Williamsburg's roads

\subsubsection{Services and additions}

On the western side of the city, four taverns have been reconstructed for use as restaurants and two for inns (Fig.15).

There are craftsmen's workshops where costumed employees work and dress as people did in the era as blacksmiths, printers, and milliners using methods from the 18th century to explain and demonstrate aspects of daily life in the past, while the visitor pass colonial sites, visit authentic trade shops (Fig.16, 17). Colonial Williamsburg restoration extend to Merchants Square where retail shops were grouped, a
Colonial Revival commercial area designated a historic district in its own right (Fig.18).

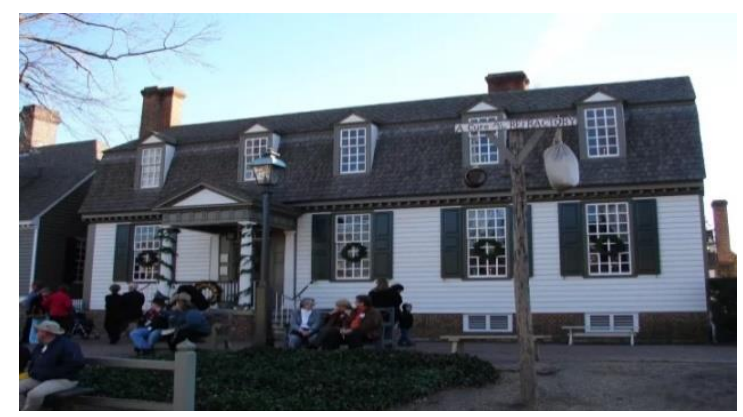

Fig.-15. Kings Arm Tavern is one of the restaurants in the Historic Area of Colonial Williamsburg.
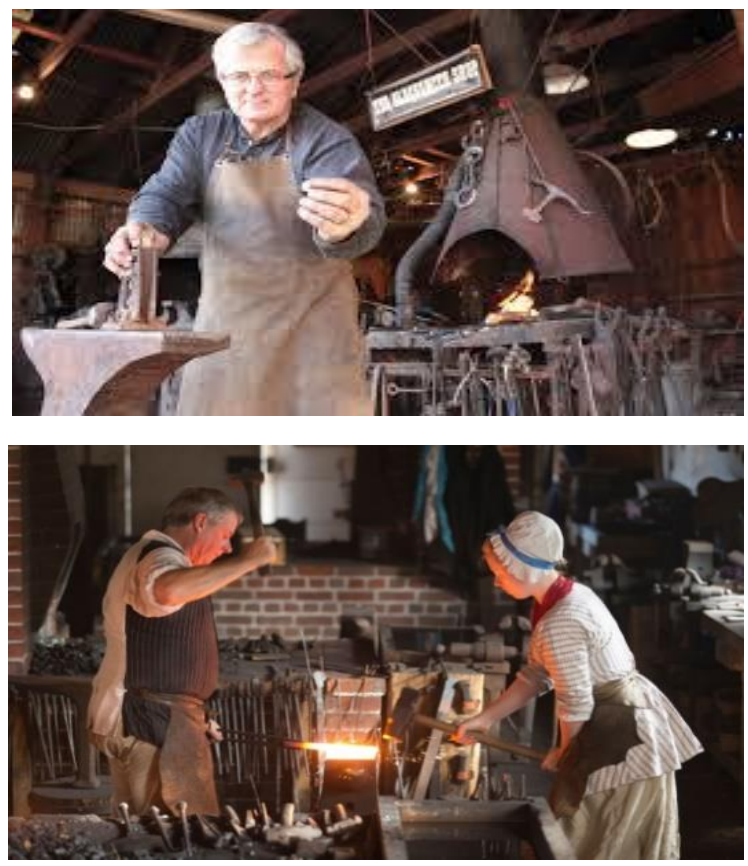

Fig.-16, 17. The craftsmen's workshops in Colonial Williamsburg.

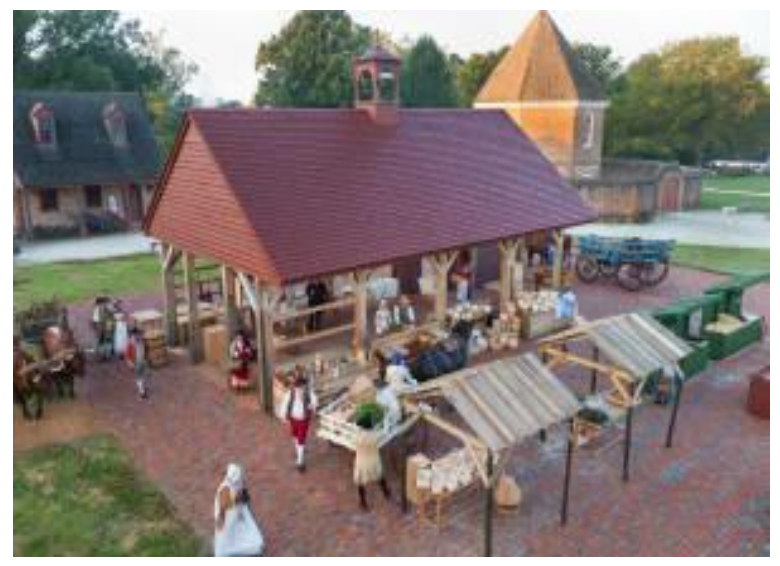

Fig.-18. The Merchants Square where retail shops were grouped 

of the Historic District Colonial Williamsburg -Virginia”

3. Environmental performance of the preservation strategy

3.1 Conservation of energy, water and other natural resources

Reclamation and reconstruction of natural resources had promoted biodiversity with preserving the important historical features of the site.

\subsubsection{Energy conservation}

The region of Colonial Williamsburg is characterized by cold climate due to the incursion of continental polar air masses, so the energy conservation procedures depend mainly on maintaining the indoors warm temperature as follows:

- The increase of houses' openings, the large areas of external openings and using of transparent glass in the windows; all these elements permit the maximum amount of sunlight taking advantage of natural lighting and warm indoors, which in turn reduce the energy consumption. (Fig.19).

- The use of thick walls of bricks in buildings help in reducing the heat loss (Fig.20).

- Using the original paint colors and finishes improves the efficiency of the building thermally.

Reduce the area of paved surfaces and parking reduces the impact of thermal and the energy consumption [10].

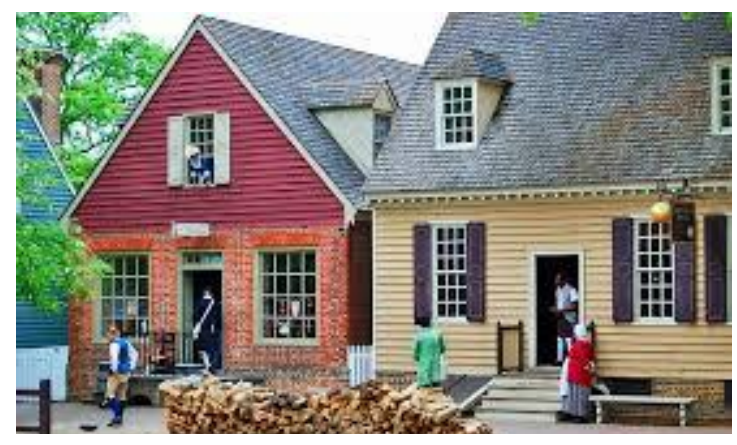

Fig.-19. shows the large areas of external openings and using of transparent glass in the windows

\subsubsection{Water conservation}

Although Colonial Williamsburg is characterized by a humid wet climate (it rains in summer between 635-1016 mm, while in April which is the driest month it reaches $77 \mathrm{~mm}$ of precipitation); water conservation was taken into consideration as follows:

- Using high efficiency irrigation technology reduced the consumption and sanitation at the site.

- Selection of low-water plants and crops and use alternatives to potable water in sewage, heating and air-conditioning such as recycled water or rainwater.
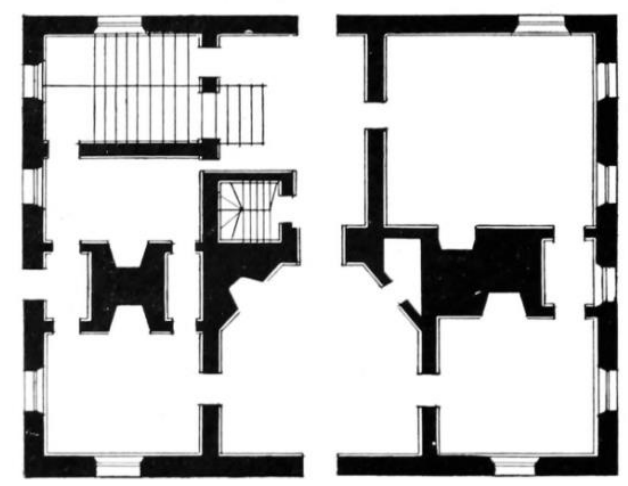

Fig.-20. the original ground floor plan of the Governor's using thick walls of bricks

\subsection{Using eco-friendly construction materials}

The preservation plan was reducing the addition of new and/or incompatible materials by performing the following steps:

- Using local materials such as bricks and wood in the buildings, and interlock tiles and basalt in the roads (Fig.21, 22).

- Using recycled materials

- Re-adjustment of existing structures and refurbishment of original materials and equipment except in case of inefficiency (Fig.23) [11].

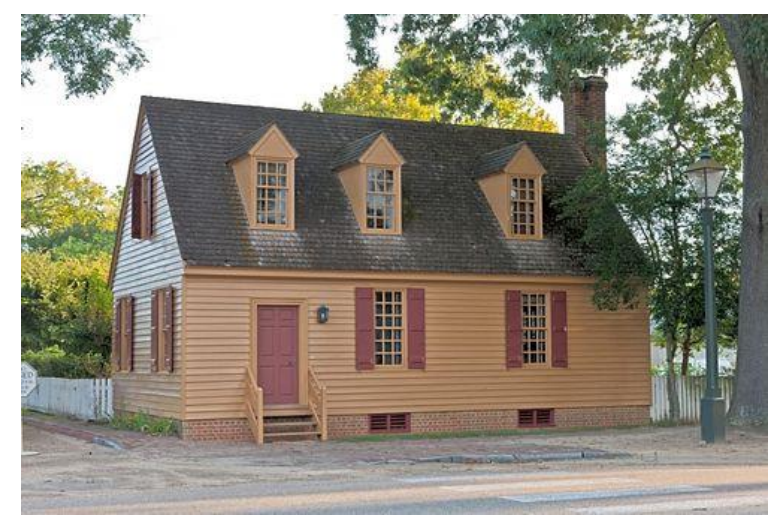

Fig.-21. Using local materials; bricks and wood in the buildings

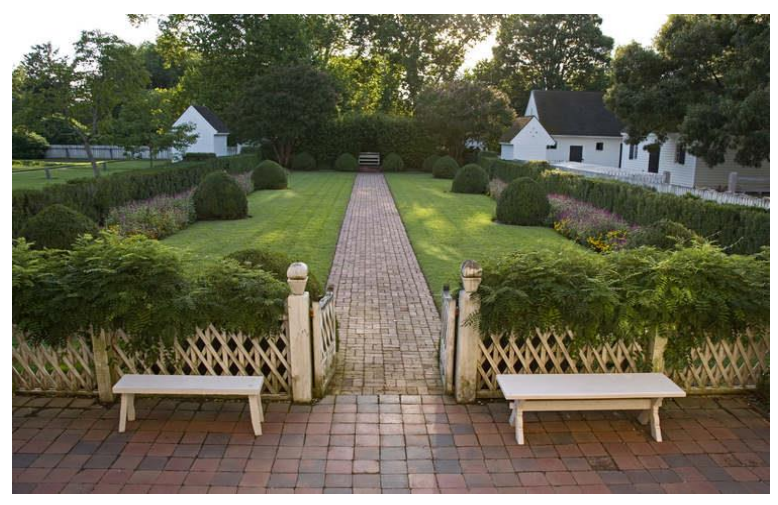

Fig.-22. Using interlock tiles in the roads 


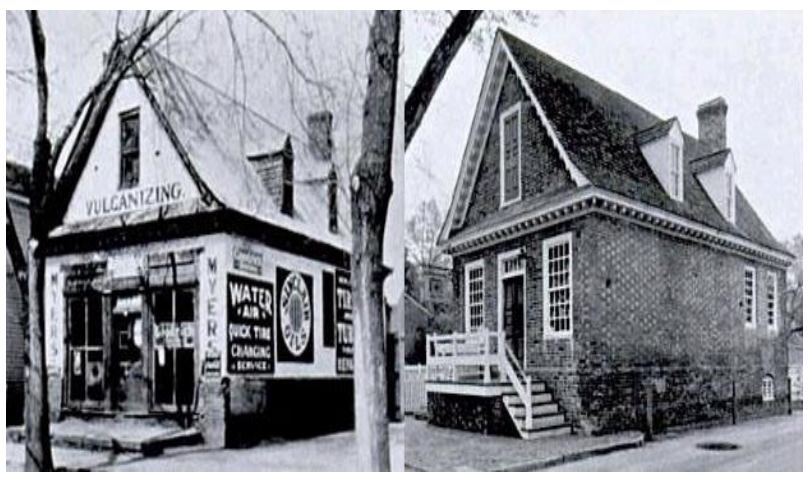

Fig.-23. The Prentis Store showing the re-adjustment of existing structures during the restoration

\subsection{Maintaining air and natural lighting quality}

It had been noticed that the original urban design of Colonial Williamsburg achieved both ventilation and natural lighting efficiently. Accordingly the preservation strategy was directed to preserve the historical area's style and the old streets which are characterized by the following:

- The direction of buildings within the historical site to the east and south where they receive the air coming from the west and south-west.

- Roads are surrounding the buildings, which lead to good sun exposure and ventilation to the external perimeter of the buildings.

- The urban fabric of the old city is characterized by a regular grid pattern with open spaces in front and around the buildings, which contributes the collection of sunlight and air movement (Fig.24) [12].

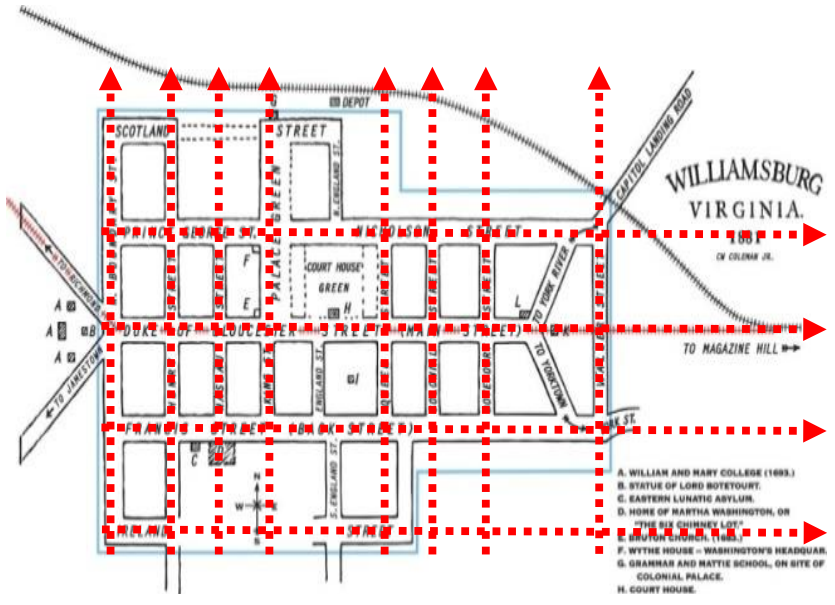

Fig.-24. the urban fabric of the old city is a regular grid pattern; in which the roads are surrounding the buildings
- Most of the buildings are single-floor and maximum high three floors where the proportion of space to the mass is averaged from 1to7, allowing permanent and sustained air movement (Fig.25).

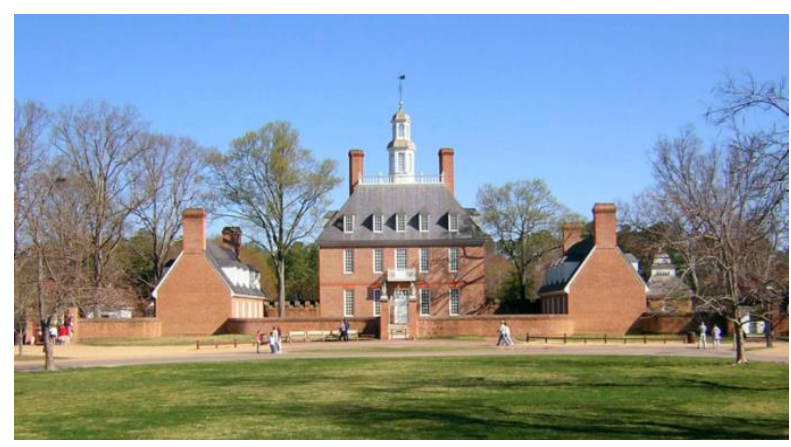

Fig.-25. the proportion of open spaces to the mass allowing permanent and sustained air movement

\subsection{Compatible Architecture character with Environment}

The preservation strategy established binding terms in order to achieve a compatible architecture character with Environment such as:

- The necessary additions to the historical buildings were put on the roofs, balconies or on the unclear side of the building in a way that don't affect the historical appearance of the buildings.

- Prevent adding new elements such as windows to preserve the environmental sustainability of the building.

- Conservation of the pyramid roofs and tiles, which reduces the accumulation of snow or rain on the buildings' roofs.

- Taking precautions to prevent the buildings damage by maintaining the infrastructure.

\subsection{Site planning}

Several modifications, transformations and additions were done to the site planning in order to be compatible with converting the district to a tourist area though eco-friendly procedures such as:

- Creating a vital greenbelt, transformation of the regional road outside the historic region and preventing the vehicles movement within the area to reflect the image required for the city, which in turn reduced the environmental pollution in the historic district (Fig.26). 


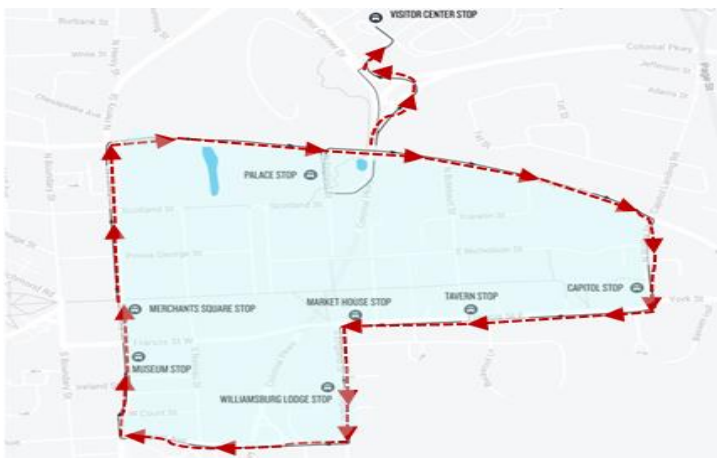

Fig.-26. the regional road is outside the historic region

The squares, open spaces and roads that form an important component of the district have helped the friendly environment transportations. The areas outside the historic district had been turned to be parking for the tourist transport buses, while roads and sidewalks were provided for pedestrians, also routes and parking spaces for bicycles and animaldrawn vehicles were planned (Fig.27).

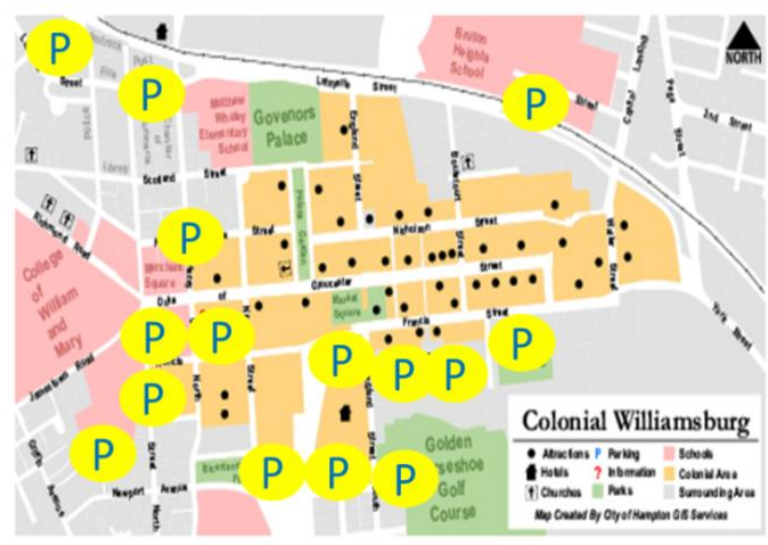

Fig.-27. the areas outside the historic district which had been turned to be parking for the tourist transport buses

- Some spaces have been converted into eco-friendly open commercial markets and services; as they are designed in historical style depending on traditional non-polluting methods for transporting goods, cooking food and others.

- Re-design the parks site to be a recreational area for visitors in addition to its environmental impact (Fig.28).

The area is characterized by moderate and cold climate, which has improved the agricultural environment so plants and trees were planted, especially those working as shading and windbreaks (Fig.29).

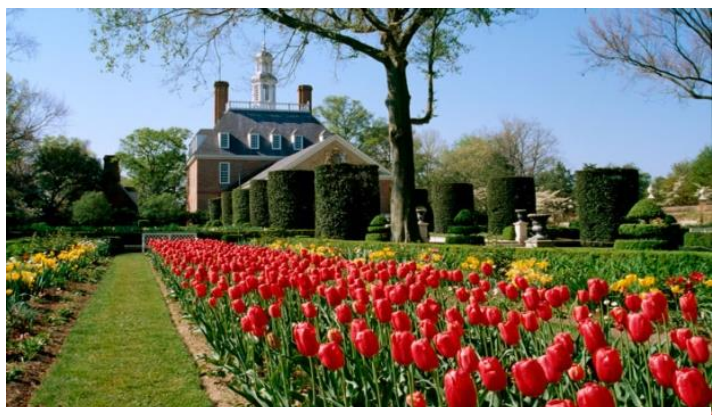

Fig.-28. Re-design the parks site to be a recreational area for visitors

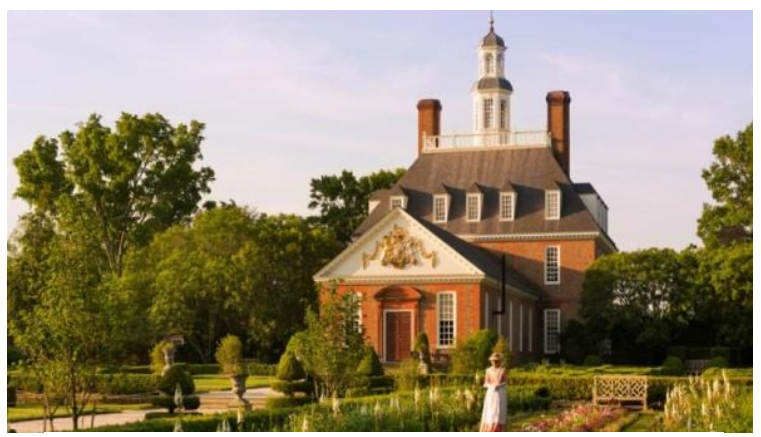

Fig.-29. Trees were planted, especially those working as shading and windbreaks

- Some open spaces and roads had been used in ecofriendly activities through performing historical scenes by employees dressed as people did in the era to explain and demonstrate aspects of daily life in the past, while the visitor pass colonial sites, and explore 18th-century homes and gardens (Fig.30).

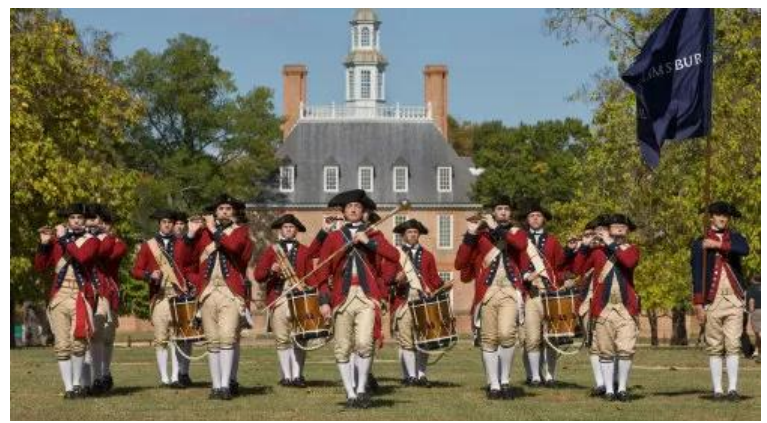

Fig.-30. performing historical scenes 


\section{Safaa A. Hefnawy, Walaa H. Hussien "Environmental Performance Assessment for the Preservation of the Historic District Colonial Williamsburg -Virginia"}

\section{Conclusions}

In this paper; we presented the analysis of a tangible example of a preservation strategy used in Colonial Williamsburg and assesses the environmental performance of the district. It had been concluded that increasing the consideration of the environmental performance of the preservation strategy achieves the sustainability of the preservation.

We elicited that the environmental performance of the preservation strategy should be implemented through major points which are:

- Preservation strategies of the historic district should adopt the original designs of the buildings, landscape and streets whether by restoration or rebuild; as the original designs were environmentally compatible.

- It should be taken into consideration the balance when determining the heritage area and its surrounding context, to avoid any disruptive of the continuity of the contemporary urban fabric and the dichotomy of services and infrastructure.

- Creating a vital greenbelt surrounding the historic district plays a main role in converting it to an ecofriendly area; moreover it will help preventing the vehicles movement within the area which in turn reduces the environmental pollution in the historic district.

- Creating ecological visits through setting the stage for visitors in their journey from modern day life into the district history time preserves the natural environment and protects the archaeological site.

- Protection of the area from exotic models and nonlocal building materials; leads to the distinctive use of these important historic buildings and thus upgrading tourism and environmental aspect of the district.

\section{References}

[1] Balz, Dan (October 12, 2007). "Painting America Purple". The Washington Post, Retrieved, 2007.

[2] "Wren Building: Oldest academic structure in America". History.org. The Colonial Williamsburg Foundation. Retrieved August 18, 2016.

[3] Greenspan, A. (2009) Creating Colonial Williamsburg: the Restoration of Virginia's Eighteenth Century Capital. 2nd edition. Chapel Hill: University of North Carolina Press.

[4] Carson, C. (1981) Living Museums of Everyman's History. Harvard Magazine.

[5] J. Kim \& B. Jeon, Restoration of a Historic Town to Commemorate National Identity: Colonial Williamsburg in the Early Twentieth
Century, Journal of Asian Arch. and Building Eng.g, 2012.

[6] McDonald, T. C. (2006/2007) The Fundamental Practice of Fieldwork at Colonial Williamsburg. Perspectives in Vernacular Architecture,

[7] "WPA_Guide: Colonial Williamsburg: The Corporate Town-Reactions". Retrieved November 2016.

[8] "Colonial Williamsburg sells Carter's Grove Plantation after bankruptcy". Retrieved November 2016.

[9] McClelland, Linda Flint (1998). Building the National Parks: Historic Landscape Design and Construction, p. 224. Baltimore: The Johns Hopkins University Press.

[10] Kibert, Charles j., "sustainable const., green building design and delivery", 2009, j. wiley\& sons, inc.

[11] De Filipi, Francesca, 2005 " Sustainable Living heritage conservation through community" based approach, paper presented at the forum UNESCO University and Heritage, 10 International Seminar.

[12] D. Mackezie: "Green Design - Design for Environment" second ed., Laurence King, England, 1997. 